\title{
Infertility profile, psychological ramifications and reproductive tract infection among infertile women, in northern upper Egypt
}

\author{
Hanan Elzeblawy Hassan * \\ Faculty of Nursing, Beni-Suef University, Beni-Suef, Egypt
}

Received: October 29, 2015

Accepted: December 10, 2015 Online Published: December 21, 2015

DOI: $10.5430 /$ jnep.v6n4p92

URL: http://dx.doi.org/10.5430/jnep.v6n4p92

\begin{abstract}
Background and objective: Reproductive tract infections (RTI) can have serious consequences, such as miscarriage and infertility. Infertility is a growing universal phenomenon, "crossed nearly all cultures and societies almost all over the World", that has a tremendous impact on women's quality of life and their psychological well-being. This is due to various stress and anxiety factors experienced by them at each stage of their life. To decrease and prevent developing psychological distress the psychological aspects of infertility should be receive more attention. The objectives of this study were to assess the prevalence rate of reproductive tract infections and the psychological consequences amongst those women who were infertile in relation to their sociodemographic characteristics, fertility history, assisted reproductive technology (ART) and RTI.

Methods: Interview questionnaire with a convenience sample of 399 infertile women who were admitted to inpatient wards and/or attending to outpatient gynecological and infertility clinics at University Hospital, Health insurance Hospital and general Hospital in Beni-Suef City.

Results: About $27.6 \%$ of study subjects had reproductive tract infections. Socio-cultural factors, gynecological issues, reproductive tract infections aggravated psychological distress amongst those women who were infertile in Northern Upper Egypt. A highly statistically significant deviation was observed $(p=.000)$.

Conclusions: Negative psychological consequences of childlessness are common and morbid in Northern, Upper Egyptian infertile women. Furthermore, infertility and psychological distress are associated in a complex way, which has to be taken care by the nurses and the clinicians to promote the quality of life of the women undergoing infertility treatment.
\end{abstract}

Key Words: Infertility, Reproductive tract infection, Assisted reproductive technology, Psychological distress

\section{INTRODUCTION}

In the recent years fertility rates have been declining rapidly in the western industrial countries due to delayed marriage, primary infertility, high divorce rate and postponed childbearing. This appears in part of some women who tend to defer child birth until the mid to late 30 s and the associated decrease in fertility after the age of $355^{[1,2]}$ In contrast, in the developing world, at that place is a little voluntary effort to delay childbearing and early first marriage is common. ${ }^{[3]}$

Infertility or failure to achieve pregnancy is a universal phenomenon. ${ }^{[4]}$ Epidemiological data indicate that infertility is estimated to involve as many as 186 million people worldwide. It is viewed by experts in the battlefield to be a problem that affects $15 \%$ to $20 \%$ of couples. ${ }^{[5]}$ Its prevalence rate

\footnotetext{
*Correspondence: Hanan Elzeblawy Hassan; Email: nona_nano_1712@yahoo.com; Address: Faculty of Nursing, Beni-Suef University, Beni-Suef,
} Egypt. 
in different countries varies from $5 \%$ to $30 \%$; $20 \%$ of couples in developed countries, ${ }^{[6]} 16 \%$ of couples in the United States, ${ }^{[2]}$ one in seven couples in the UK. It is further estimated that in 100 couples trying to conceive naturally, 85 will conceive within one year and 95 within 2 years, ${ }^{[7]}$ in Iran, approximately, two million couples are infertile. ${ }^{[8]}$ Worldwide approximately $40 \%$ of infertile couples have female factor infertility, $40 \%$ male factor, and $20 \%$ a combination of both or infertility of unknown etiology. ${ }^{[2]}$

Microbial infection of the female genital tract is most common and of greatest economic importance in humans. Many of the mechanisms underlying the identification of microbial pathogens by the innate immune system have been identified during recent years. ${ }^{[9]}$ Reproductive tract infections (RTI), generally, seen as a silent epidemic can have serious outcomes, including spontaneous abortion, ectopic pregnancy, infertility, chronic pelvic pain, neonatal blindness, increased risk of HIV infection and even death. ${ }^{[10,11]}$ About $35 \%$ of infertility problems are identified as inflammatory changes of the oviduct and/or surrounding peritoneum that interfere with tuboovarian function as well as disrupting uterine function, most of these alterations result from RTI. Salpingitis occurs in $15 \%$ of reproductive age women and approximately $2.5 \%$ of all women become infertile as a result of salpingitis by age $35 .^{[12]}$

Chlamydia trachomatis infections, as well as mixed anaerobic infections, are the most dominant causes of upper genital tract infections while bacterial vaginosis, Trichomonas vaginalis \& Candida alpacas, protozoan \& fungal causes are the most prevalent of lower genital tract infections. Regrettably, adult females are twice as likely as males to acquire Chlamydia during a single act of unprotected intercourse with an infected partner. Chlamydia signs \& symptoms are often minimal or nonexistent. Many newly infected women have no symptoms and therefore don't seek medical intervention; thus spreading the infection to other sexual partners. Chlamydia is the major cause of pelvic inflammatory disease (PID) and tubal factor infertility. In addition, it may also contribute to chronic inflammation of the cervix \& endometrium, alterations in reproductive tract secretions, induction of immune mediators that interfere with gamete or embryo physiology, and structural disorders such as intrauterine synechiae. Moreover, endometrial infections may follow procedures that alter the usual protective role of the cervix, such as cervical conization or procedures associated with the entry of contaminated cervical mucus into the womb. Endometrial biopsy, hysterosalpingography, may predispose to endometritis \& ascending genital tract infection. Secondary infections of the endometrium may follow primary invasion with C. Trachomatis. An estimated $10 \%$ to $20 \%$ of untreated women

Published by Sciedu Press with endocervical Chlamydia infection eventually develop salpingitis. ${ }^{[12]}$

As reproduction is believed to be one of the main basic necessities of humans, a psychological crisis may occur when something interferes with their ability to reproduce. ${ }^{[13]}$ In the mid 1980s researchers, obstetricians, gynecologists, and nurse midwives began questioning the hypothesis that psychological distress caused infertility. Instead, they found that psychological distress was a result of infertility. With this reason, psychological health professionals have become progressively involved with gynecologists in the provision of care to infertile patients. ${ }^{[2]}$ Despite the endless medical \& nursing research of infertility, the Psychological aspects of infertility have not been adequately addressed. Written reports on infertility are voluminous, and have shown that involuntary childlessness can be emotionally withering, and it may involve a stronger psychological distress. ${ }^{[14]}$ This distress could affect the relationship between husband and wife. The infertile individuals usually experience numerous emotional reactions like anxiety, stress, and depression. ${ }^{[15]}$

Previous studies indicate that the prevalence of symptoms of depression and anxiety among adult females who were infertile is relatively high. Mild depression symptoms have been reported in $12 \%$ to $54 \%$ of women during infertility treatments. In addition, $12 \%$ to $23 \%$ of them have been reported to suffer anxiety disorders. ${ }^{[16]}$ Assisted reproductive technology (ART) or reproductive aiding technologies like in vitro fertilization (IVF) and intracytoplasmic sperm injection (ICSI) are complex \& considered the most stressful techniques used to treat infertility. The waiting period between embryo transfer \& pregnancy test as well as the failure of such pregnancy attempts is described as presenting great strains for infertile women. ${ }^{[17]}$ Undergoing ART presents physical \& emotional burden associated with high degrees of depressive symptoms, anxiety \& stress. In summation, the stress surrounding infertility may be attributed to the cyclical nature of the treatment or the side effects of fertility medications. ${ }^{[18]}$

Anxiety is a state of mind which develops depending on environmental stimulants that are perceived by the individuals as being dangerous or threatening and have unpleasing effects. ${ }^{[19]}$ It is well recognized that anxiety may occur at any period of the lifespan. There are many views of mundane life that provoke anxiety, various situations and conditions can increase the frequency and severity of the anxiety. ${ }^{[20]}$ Anxiety influences people's mood, expectations and motivation, and are the most prevalent mental disorders. ${ }^{[21]}$ At some time during the infertility evaluation and treatment, couples may feel intense anger. They may argue that life has treated 
them unfairly \& that their infertility is unjust. They may become intensely angry when they see individuals, whom they believe undeserving, achieve a pregnancy with little or no effort. They may feel very angry when they observe a pregnant woman displaying disgust or unhappiness with her pregnancy; when they regard women with an unwanted pregnancy seeking an abortion; or when they observe a mother or father abusing their child. ${ }^{[2]}$

Symptoms of depression are incredibly common during infertility. Being sad when you cannot easily conceive is, of course, an incredibly natural reaction. Procreation is the strongest instinct in the animal kingdom; the desire to want a baby is the most natural thing in the world. Childless ones usually tell the same story: they gleefully do away with the birth control, happily try for a few months, and then usually get somewhat worried. As time passes the worry turns into genuine concern and when they finally see a doctor, anxiety \& sadness may have already set in. By the time they see an infertility specialist, they experience the roller coaster of emotions every month, feel that absolutely everyone in their life is pregnant or has a new baby, and if one more person tells them to "just relax", they may be in danger of losing it totally. ${ }^{[22]}$

The relationship between infertility and stress can be viewed as either causative (where stress causes infertility) or reactive (where infertility causes stress). The subject areas in which researchers have analyzed the possibility that stress causes infertility have been found to negate each other. Some subject indicated a relationship \& others do not. ${ }^{[23]}$

As nurses comprise the greatest group of health care providers and are the ones responsible for the quality of care provided to the patients, their perspectives on the effectiveness of their care are very important. ${ }^{[24]}$ However, nurses possess a wide variety of holistic skills and there is evidence of nursing interventions that are proving to be valuable in treating anxiety in infertility settings. It is proposed that the nurse-patient relationship is very important and is a critical element within nursing's paradigm of patient care. Many written reports have addressed the impact of nursing on health care outcomes and those reports suggest that positive patient outcomes depend to a greater extent on the accomplishments of nurses than on the available technology. Many investigators, managers, and researchers have attempted, therefore, to define nursing's impact on and contribution to care. ${ }^{[25]}$

\subsection{Significance of the study}

In recent years, the number of couples seeking treatment for infertility has dramatically increased. This increasing participation in fertility treatment has raised awareness \& inspired investigation into the psychological ramifications of infertility. ${ }^{[26]}$ The process of undergoing an infertility work up \& subsequent treatment impact upon the individual on several levels, psychologically, physically, spiritually and financially. ${ }^{[13]}$ When the psychological implications related to human infertility had been extensively studied, the most frequent possible disturbances were anxiety, depression, low self-esteem, strong psychological tension, crisis in the marital relationship, separation, and divorce. ${ }^{[27]}$ Moreover, several reviews address stress, depressive symptoms \& anxiety in relation to fertility. ${ }^{[28]}$

A high prevalence of reproductive tract infections may result in increased rates of secondary infertility. In turn, in the developing world, is often highly stigmatized \& leads to profound social suffering for infertile women in particular. Yet, most childless people in the developing societies have virtually no access to effective treatment. ${ }^{[3]}$

Infertility is not just a medical problem to be treated with fertility drug \& surgery or ART but is a crisis that profoundly affects nearly all faces of one's life and personality. Society needs to be aware of the immensity of the crisis of childlessness, not only medically, but also psychologically. This study would highlight the psychological aspects which were negatively impacted on through the childlessness's experience. Although previous studies conducted in the Western countries have reported that psychological factors are implicated in the experience of infertility, surprisingly, there are few studies which have carefully assessed this relationship in Arab women. We postulate that with all important causal "confounds" such as age, education, gynecological impairment, reproductive tract infection, any significant difference in the psychological profile can be attributed to infertility.

\subsection{Operational definitions}

Infertility: Infertility, as defined by the World Health Organization, is a disease of the reproductive system defined by the failure to achieve a clinical pregnancy after 12 months or more of regular unprotected sexual intercourse, without the use of contraception. ${ }^{[29]}$

Primary infertility: Couples who have been no prior conception after at least one year, having sex without usage birth control methods. ${ }^{[30]}$

Secondary infertility: Couples who have been able to get pregnant at least once, but now are unable to conceive. ${ }^{[30]}$

Psychological distress: A state of emotional suffering that may impact on social functioning and day to day living of individuals characterized by symptoms of depression, anxiety, stress and tension. ${ }^{[31,32]}$ 
Primary dysmenorrhea: Painful menses in women with normal pelvic anatomy. ${ }^{[33]}$

ART or reproductive aiding technologies: Originally, a range of techniques for manipulating oocytes $\&$ sperm to overcome infertility; encompasses drug treatments to stimulate ovulation, surgical methods for removing oocytes (laparoscopy \& ultrasound-guided transvaginal aspiration) and for implanting embryos (zygote intrafallopian transfer or ZIFT, tubal embryo transfer or TET), in vitro \& in vivo fertilization (artificial insemination \& gamete intrafallopian transfer or GIFT), ex utero and in utero fetal surgery, \& laboratory regimes for freezing and screening sperm \& embryos as well as micromanipulation \& cloning embryos as well as. ${ }^{[34]}$ IVF, GIFT, ZIFT, and TET are very similar procedures although there are a few significant differences. During IVF, ZIFT, and TET, the eggs (oocytes) and sperms are combined in a culture dish in the laboratory. Fertilization and very early embryo development occur outside the body, rather than in the Fallopian tube. Once, early embryo development is recognized, the embryos are transferred either into the uterus (IVF) or the Fallopian tube (ZIFT, TET). ${ }^{[35]}$

\subsection{Aim of the study}

The aims of the study were to assess the sociodemographic characteristics \& gynecological problems and prevalence of reproductive tract infection among adult females with infertility, to find out and highlight the psychological implications, particularly psychological distress, (stress or tension/anxiety/depression) among women with infertility and to correlate the findings with their demographic variables as well as gynecological issues and reproductive tract infections.

\subsection{Research questions}

Is infertility affecting psychological status among infertile women in Northern Upper Egypt?

What is the prevalence rate of reproductive tract infections among infertile women in Northern Upper Egypt?

Are gynecological issues as well as reproductive tract infection significantly implicated in women's psychological distress among infertile women in Northern Upper Egypt?

\section{SUBJECTS AND METHOdS}

\subsection{Research design}

An exploratory design was selected for the current study to appraise the relationship between gynecological issues such as reproductive tract infection, and psychological implication among infertile women in Northern Upper Egypt mainly Beni Suef city.

Published by Sciedu Press

\subsection{Research setting}

This study encompassed all governmental hospitals in BeniSuef City, University Hospital, Health insurance Hospital and general Hospital, which affiliates to Ministry of Health (MOH), where infertile women were admitted to gynecological inpatient wards and/or attending to gynecologic and infertility outpatient clinics.

\subsection{Subjects}

A convenience sample of 399 infertile women were enrolled in this study.

- All subjects fulfilled the following eligibility criteria:

- At fertility age (15-45).

- Duration of marriage more than 1 year.

- Has regular sexual intercourse without the functional use of contraceptive methods.

- Not having any psychological treatment.

- Exclusion criteria:

- Women who have any previous psychological disease or treatment.

\subsection{Tool of data collection}

A Structured interviewing questionnaire was designed by the researcher after reviewing related literature. It was written in the Arabic language to suit women's level of intellect in the form of closed and open-ended queries. It covered three main parts as follows:

The first part included sociodemographic and personal data such as age, age at marriage, income adequacy and duration of the marriage. The second part included a structured infertility questionnaire sheet, was modified by the researcher which based on Atlantic Assisted Reproductive Therapies Suite 213, 1535 Dresden Row, Halifax, NS B3J 3T1 (902) 404-8600, AART FRM Clin066 20100503. Infertility Questionnaire (Female). ${ }^{[36]}$ It consisted of three sections:

- Section I: Obstetrical history, such as history and figure of previous pregnancy miscarriage.

- Section II: Gynecological history, such as age at first period, menstrual disturbances, menstrual related pain, Reproductive tract infections and its type.

- Section III: Infertility history, such as infertility type and duration, trials and types of treating infertility using ART.

The third part included questionnaires for an infertility sequel as psychological distress to assess women's, data were collected utilizing the psychological scales. It consisted of three sections:

- Section I: An Arabic version of the Beck depression inventory (BDI) was developed by Yusuf (2008). ${ }^{[37]}$ It 
consists of 20 questions; Each one depicts a specific behavioral manifestation of depression. Responses were assessed in 4 points Likert Scale, where the highest score indicated the highest level of symptom intensity, ranging from "0 to 3" as " 0 " no symptoms, "1" Quite a few, "2" Sometimes, "3" Yes, often. The scope of the possible score is from " 0 " to " 60 ".

- Section II: An Arabic edition of the Taylor scale was developed by Fahmy \& Ghally. ${ }^{[38]}$ A state scale consists of 50 statements, asked the patients to describe how they generally feel. The subject responded to each item by rioting on a point scale. Each item was assigned a score of " 1 " given when the symptom was present, a score " 0 " was given when the symptom was absent. The range of possible score is from " 0 " to "50". [39]

- Section III: A structured tension/stress questionnaire sheet was modified by the researcher which based on Psychometric Properties of The Depression Anxiety
Stress Scale 42 (DASS). The Stress scale is sensitive to levels of chronic non-specific arousal. It assesses difficulty relaxing, nervous arousal, and being easily upset/agitated, irritable/over-reactive and impatient. ${ }^{[40]}$ It consists of nine questions; each one depicts a specific behavioral manifestation of tension. Responses were measured in 4 points Likert Scale, where the highest score indicated the highest level of symptom intensity, ranging from " 0 to 3 " as " 0 " absence of symptoms, "1" Quite a few, "2" Sometimes, "3" Often, often. The range of possible score is from " 0 " to " 27 ".

\section{Scoring system}

Psychological distress can be evaluated according to the Table below. In brief, non morbid levels of psychological distress are these ups and downs (absent, mild, moderate symptoms) and it is no need for intervention or a psychologist referral while, morbid levels (severe, extremely severe) need for intervention or psychologist referral.

Table 1. Scoring system of psychological distress

\begin{tabular}{lllll}
\hline \multirow{2}{*}{ Classification of psychological distress } & \multirow{2}{*}{ Level } & Total Score & & \\
\cline { 3 - 5 } & & Depression & Anxiety & Tension/Stress \\
\hline \multirow{2}{*}{ Non morbid level } & No/Without & $0-10$ & $0-16$ & $0-8$ \\
& Mild & $11-16$ & $17-19$ & $9-12$ \\
\multirow{2}{*}{ Morbid level (Significant morbidity indicators) } & Moderate & $17-30$ & $20-24$ & $13-17$ \\
& Severe & $31-40$ & $25-36$ & $18-21$ \\
& Extremely Severe & $40+$ & $37+$ & $22+$ \\
\hline
\end{tabular}

\subsection{Methods of data collection}

This study was covered in the following phases.

\subsubsection{Validity of tool}

The study tool was reviewed \& tested for content validity by five experts from maternity \& gynecological nursing professor, obstetric \& gynecological medicine professor, and psychological health professor.

\subsubsection{Reliability}

Internal consistency, reliability was assessed by Cronbach's alpha coefficient. The internal reliability of the instruments was 0.84 .

\subsubsection{Administrative considerations}

Approval was taken from hospitals directors before taking up the research. Written letters, describing the purpose of the study were issued from the Dean of the Faculty of Nursing, Beni Suef University, to the Directorate of University Hospital, Health Insurance Hospital and General Hospital in Beni Suef to obtain the permit to gather the research sample from Hospitals under their directorate.

\subsubsection{Ethical considerations}

Data were collected after explaining the purpose of the study to all infertile women who took part in the study. Confidentiality of the information gathered was assured clearly for every participant in the study. Verbal consent from every woman before the outset of the interview was taken.

\subsubsection{Pilot study}

The pilot study included about $10 \%$ of the study sample. The pilot settings, selected in this study were included in the original study subject, but the pilot sample was excluded from the main study in order to avoid contamination of the study sample. The pilot study assessed the clarity of language, the applicability of items, and time consumed for filling in the tools' items.

\subsubsection{Field work}

Data were collected from previously mentioned settings for three days weekly, mainly Saturday, Sunday and Thursday, each week, according to the time available to women and their attendance schedule for the clinic as the doctor ordered 
and the woman's personal demands. Each woman took approximately 45-60 minutes to complete the questionnaire, also the researcher of study helped illiterate women in completing the questionnaire. The data collection took 12 months. The actual field study started July 2012 and ended June 30, 2013 for data collected from above mentioned-settings.

\subsubsection{Statistical design}

After the data were collected, they were organized, coded and transferred to specially designed formats to be suitable for computer feeding. Following data entry, revising and verification processes were carried out to avoid any errors during data entry. They were stored, tabulated and analyzed using the number and percentage distribution. Proper statistical tests were applied to decide whether there was a significant difference or not, using the statistical package for social science (SPSS), version 16.0 (SPSS, Chicago, IL, USA). The following statistical measures were used:

- Descriptive measures included count, percentage, arithmetic mean, standard deviation (Mean \pm SD).

- Relations between different numerical variables were tested using Pearson correlation.

- Statistical tests included: Chi-square $\left(\chi^{2}\right)$ test for analysis of qualitative variables.

- The graphical presentation included Bar chart diagram.

- The level of significance selected for this study was $P$ equal to or less than .05. Probability ( $p$-value) was considered as follows:

$-P>.05$ insignificant.

- $* P<.05$ mild Statistical significant.

- ** $P<.01$ moderate Statistical significance.

- *** $P<.001$ highly Statistical significant.

\section{RESUlts}

Table 2 presents the distribution of the study subjects according to their sociodemographic characteristics. It revealed the mean age, age at marriage and duration of marriage were 26 $\pm 5.18,19.74 \pm 1.61,3.83 \pm 2.21$ years respectively. $40.4 \%$ of them had Secondary or technical education, $38.6 \%$ were housewives. It was observed from the same table that the majority of the study subjects (80.7\%) did not have enough family income, $17 \%$ of them took in enough income for just living while only $2.3 \%$ of them had enough family income and can save from it.

Table 3 shows the distribution of the study subjects according to their fertility, obstetrical \& gynecological history. Firstly, the mean age at menarche of the study subjects was $15.40 \pm$ 2.20 years and more than half $(54.4 \%)$ of them had irregular menstrual cycle and dysmenorrhea, the bulk (84.7\%) of them did not get pregnant before, $13.0 \%$ of them experienced a previous abortion and the mean duration of infertility was $3.09 \pm 2.34$. Secondly, as evident from the same table that $27.6 \%$ of study subjects had reproductive tract infections. It was found that $17.5 \%$ were infected by, Bacterial vaginosis or Trichomonas vaginalis or Candida albicans while $10 \%$ were had Chlamydia infections. Moreover, it was noticed that $14.0 \%$ of the studied subjects tried to get pregnant through assisted reproductive technology (ART); $5.5 \%$ of them by Artificial insemination, $6.3 \%$ by in vitro fertilization IVF, and only $2.3 \%$ by intra cytoplasmic sperm injection ICSI).

Table 2. Distribution of the studied sample according to their sociodemographic characteristics

\begin{tabular}{|c|c|c|}
\hline Variables & \multirow{2}{*}{ Frequency } & \multirow{2}{*}{$\begin{array}{l}\text { Percent } \\
(\%)\end{array}$} \\
\hline Women characteristics & & \\
\hline Age (mean \pm SD) & $26 \pm 5.18$ & \\
\hline$<25$ & 97 & 24.3 \\
\hline $25-40$ & 280 & 70.2 \\
\hline$>40$ & 22 & 5.5 \\
\hline Age at marriage (mean $\pm \mathrm{SD})$ & $19.74 \pm 1.61$ & \\
\hline$<20$ years & 210 & 52.6 \\
\hline$\geq 20$ years & 189 & 47.4 \\
\hline Marriage duration (mean \pm SD) & $3.83 \pm 2.21$ & \\
\hline$<5$ years & 293 & 73.4 \\
\hline$\geq 5$ years & 106 & 26.6 \\
\hline \multicolumn{3}{|l|}{ Educational level } \\
\hline Illiterate & 111 & 27.8 \\
\hline Primary education (read and write) & 52 & 13.0 \\
\hline Secondary or technical education & 161 & 40.4 \\
\hline University education & 75 & 18.8 \\
\hline \multicolumn{3}{|l|}{ Occupational status } \\
\hline Working & 245 & 61.4 \\
\hline Jobless (housewife) & 154 & 38.6 \\
\hline \multicolumn{3}{|l|}{ Occupation type } \\
\hline No occupation & 156 & 39.1 \\
\hline Officer (employee) & 121 & 30.3 \\
\hline Trader or dealer & 36 & 9.0 \\
\hline Skilled job (professional) & 67 & 16.8 \\
\hline Other jobs & 19 & 4.8 \\
\hline \multicolumn{3}{|l|}{ Family income adequacy } \\
\hline Always not enough & 202 & 50.6 \\
\hline Sometimes not enough & 120 & 30.1 \\
\hline Just enough (enough for living only) & 68 & 17.0 \\
\hline Enough \& can save from it & 9 & 2.3 \\
\hline
\end{tabular}


Table 3. Distribution of the studied sample according to their fertility, obstetrical \& gynecological history

\begin{tabular}{|c|c|c|}
\hline Variables & Frequency & Percentage (\%) \\
\hline Age at menarche (mean \pm SD) & $15.40 \pm 2.20$ & \\
\hline \multicolumn{3}{|l|}{ Menstrual disturbances } \\
\hline Yes (irregular menstrual cycle) & 217 & 54.4 \\
\hline No (regular menstrual cycle) & 182 & 45.6 \\
\hline \multicolumn{3}{|l|}{ Menstruation-related pain (dysmenorrhea) } \\
\hline Yes & 217 & 54.4 \\
\hline No & 182 & 45.6 \\
\hline \multicolumn{3}{|l|}{ Infertility type (History of pregnancy) } \\
\hline Primary (never got pregnant) & 338 & 84.7 \\
\hline Secondary (had pregnancy before) & 61 & 15.3 \\
\hline Infertility duration (mean \pm SD) & $3.09 \pm 2.34$ & \\
\hline \multicolumn{3}{|l|}{ History of pregnancy miscarriage } \\
\hline No & 347 & 87.0 \\
\hline Yes & 52 & 13.0 \\
\hline \multicolumn{3}{|l|}{ Number of previous pregnancy miscarriage } \\
\hline 0 & 347 & 87.0 \\
\hline Once & 45 & 11.3 \\
\hline Twice or more & 7 & 1.8 \\
\hline \multicolumn{3}{|l|}{ History of reproductive tract infection } \\
\hline Yes & 110 & 27.6 \\
\hline No & 289 & 72.4 \\
\hline \multicolumn{3}{|l|}{ Type of reproductive tract infection } \\
\hline No & 289 & 72.4 \\
\hline Bacterial vaginosis, Trichomonas vaginalis, and Candida albicans & 70 & 17.5 \\
\hline Chlamydia infections & 40 & 10.0 \\
\hline \multicolumn{3}{|l|}{ Trials for assisted reproductive technology (ART) } \\
\hline Yes & 56 & 14.0 \\
\hline No & 343 & 86.0 \\
\hline \multicolumn{3}{|l|}{ Types of assisted reproductive technology (ART) } \\
\hline Not applicable & 343 & 86.0 \\
\hline Artificial insemination (AI) or Intrauterine insemination (IUI) & 22 & 5.5 \\
\hline In vitro fertilization (IVF) & 25 & 6.3 \\
\hline Intracytoplasmic sperm injection (ICSI) & 9 & 2.3 \\
\hline Gamete intrafallopian transfer (GIFT) & 0 & 0.0 \\
\hline Zygote intrafallopian transfer (ZIFT) & 0 & 0.0 \\
\hline Tubal Embryo Transfer (TET) & 0 & 0.0 \\
\hline
\end{tabular}

Distribution of frequency \& prevalence and levels of psychological distress (depression, anxiety and stress) is displayed in Figure 1. As the figure depicts that around half (40.9\%, $45.1 \%, 45.1 \%)$ of the studied subjects were having a morbid level of psychological distress (depression, anxiety and stress), respectively, and need for psychological intervention.

Table 4 summarizes the association between psychological distress outcome measures and the sociodemographic characteristics of the studied subjects. A highly statistically significant difference in psychological status amongst those women who were infertile in relation to their age, level of education, and occupation type as well as family income adequacy in regards to depression $(p=.000)$, anxiety $(p=.000)$ and tension $(p=.000)$. Moreover, statistical significant difference in depression $\&$ anxiety $(p=.000, .031)$, respectively, amongst 
those infertile women in relation to their age at marriage. of marriage, the same table shows decreasing psychologiHowever, there was no statistical significant difference in psychological status (except in depression $p=.004$ ) amongst those women who were infertile in relation to their duration cal distress percentage by increasing age at marriage and lengthening of marriage time.

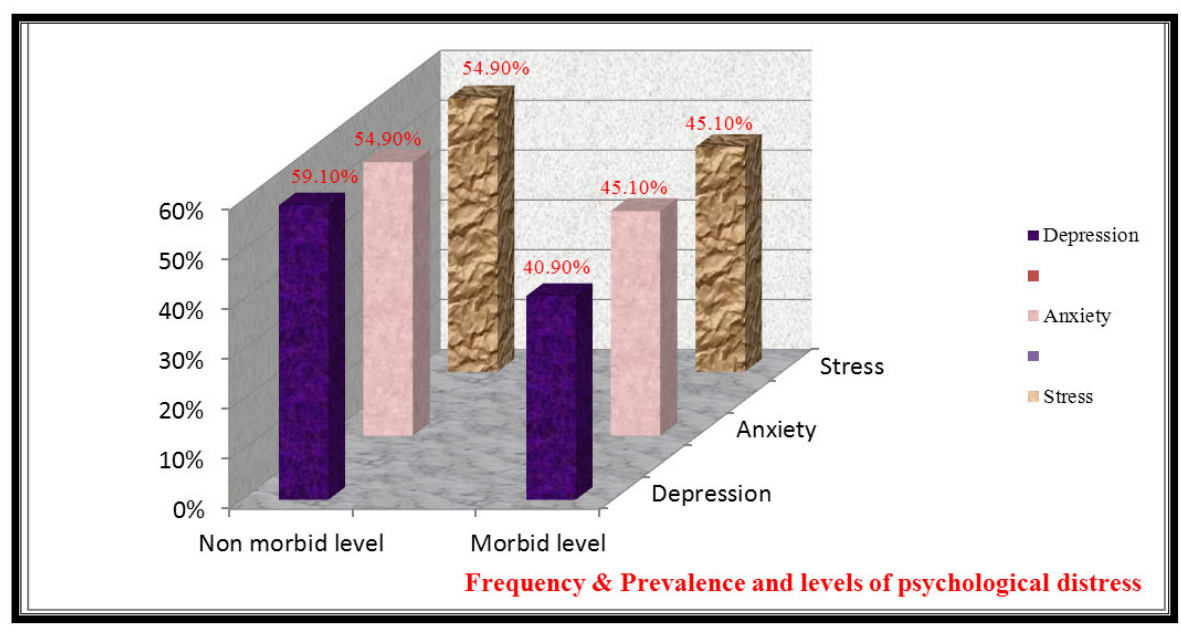

Figure 1. Distribution of the studied sample as regards prevalence of psychological distress

The association between psychological distress (depression, anxiety \& stress) outcome measures of the studied subjects and their fertility, obstetrical and gynecological history are illustrated in Table 5. This table demonstrates a statistically significant impact of menstrual disturbances, dysmenorrhea, previous abortion, reproductive tract infections and type of infection as well as type \& duration of infertility and type of ART used to treat infertility on psychological states which risk later in life among infertile women, which in turn is predictive of occurrence of psychological distress later in life.

\section{Discussion}

Infertility is perceived as a problem across virtually all cultures and societies and affects an estimated $10 \%$ to $15 \%$ of couples of reproductive age (American Society for Reproductive Medicine [ASRM, 2008]). ${ }^{[41]}$ Motherhood is one of the major transitions in adult life for women. The nonfulfillment of a wish for a child is received as a stressful situation. It has been associated with emotional and psychological sequelae, including stress, tension, anxiety and depression, Couples may experience stigma, sense of loss, \& diminished self-esteem in the setting of their infertility. ${ }^{[26,42]}$

The descriptive information about the psychological aspects of infertility was derived from research conducted and reported in the mid-1980s. There has been a growing body of research on the relationship between psychological aspects and infertility. These works started by documenting the psy- chological stress related to treatment and have proceeded to examine whether there is a causal relationship between psychological stress \& infertility. ${ }^{[2]}$ In recent years, special attention has been yielded to the psychological health issues of infertile couples. Grief reactions are the most common among them, even so, these normal grief reactions may become prolonged thus becoming pathological leading to major depression. ${ }^{[43]}$ Soltani (2014) documented that, the psychological crisis and the concerns caused by infertility affect directly on physiological functions of body and ultimately, a negative influence on infertility. The relaxed and healthy individuals experience less psychological tensions. ${ }^{[15]}$

Despite infertility implies a tremendous psychological impact on infertile couples, and that influence their relationships with their spouses, as well as, may increase the duration of infertility, no local study was found to assess the prevalence of psychological distress among infertile Egyptian women in Upper Egypt. Therefore, this study processed to find out the negative psychological effect of childlessness, the prevalence of stress or tension/anxiety/depression among infertile women \& to explore the sociodemographic factors, gynecological implication and the prevalence rate of reproductive tract infection, that may be related to and aggravate psychological distress among the infertile Egyptian women in Northern Upper Egypt. The outcomes of this study should assist to identify the status of psychological distress among infertile women and enhance the development of programs for prevention and treatment. 
Table 4. Relationship between sociodemographic characteristics of the studied subjects and their psychological distress

\begin{tabular}{|c|c|c|c|c|c|c|c|c|c|}
\hline \multirow{2}{*}{$\begin{array}{l}\text { Variables } \\
\text { Women characteristics }\end{array}$} & \multicolumn{3}{|c|}{ Depression } & \multicolumn{3}{|l|}{ Anxiety } & \multicolumn{3}{|c|}{ Tension/Stress } \\
\hline & $\begin{array}{l}\text { Non } \\
\text { Morbid }\end{array}$ & Morbid & $\boldsymbol{P}$ & $\begin{array}{l}\text { Non } \\
\text { Morbid }\end{array}$ & Morbid & $\boldsymbol{P}$ & $\begin{array}{l}\text { Non } \\
\text { Morbid }\end{array}$ & Morbid & $\boldsymbol{P}$ \\
\hline \multicolumn{10}{|l|}{ Age } \\
\hline \multirow{2}{*}{ Below 25 years } & 72 & 25 & \multirow{8}{*}{.000} & 70 & 27 & & 73 & 24 & \\
\hline & $30.5 \%$ & $15.3 \%$ & & $32.0 \%$ & $15.0 \%$ & & $33.3 \%$ & $13.3 \%$ & \\
\hline \multirow{2}{*}{$25-40$ years } & 160 & 120 & & 142 & 138 & & 141 & 139 & \\
\hline & $67.8 \%$ & $73.6 \%$ & & $64.8 \%$ & $76.7 \%$ & 000 & $64.4 \%$ & $77.2 \%$ & 000 \\
\hline \multirow{2}{*}{ Above 40 years } & 4 & 18 & & 7 & 15 & . & 5 & 17 & .000 \\
\hline & $1.7 \%$ & $11.0 \%$ & & $3.2 \%$ & $8.3 \%$ & & $2.3 \%$ & $9.4 \%$ & \\
\hline \multirow{2}{*}{ Total } & 236 & 163 & & 219 & 180 & & 219 & 180 & \\
\hline & $100.0 \%$ & $100.0 \%$ & & $100.0 \%$ & $100.0 \%$ & & $100.0 \%$ & $100.0 \%$ & \\
\hline \multicolumn{10}{|l|}{ Educational level } \\
\hline \multirow{2}{*}{ Illiterate } & 70 & 41 & \multirow{8}{*}{.004} & 49 & 62 & & 49 & 62 & \\
\hline & $29.7 \%$ & $25.2 \%$ & & $22.4 \%$ & $34.4 \%$ & & $22.4 \%$ & $34.4 \%$ & \\
\hline \multirow{2}{*}{ Primary education (read/write) } & 32 & 20 & & 32 & 20 & & 32 & 20 & \\
\hline & $13.6 \%$ & $12.3 \%$ & & $14.6 \%$ & $11.1 \%$ & 000 & $14.6 \%$ & $11.1 \%$ & 000 \\
\hline \multirow{2}{*}{ Secondary/technical education } & 82 & 79 & & 106 & 55 & .000 & 91 & 70 & .000 \\
\hline & $34.7 \%$ & $48.5 \%$ & & $48.4 \%$ & $30.6 \%$ & & $41.6 \%$ & $38.9 \%$ & \\
\hline \multirow{2}{*}{ University education } & 52 & 23 & & 32 & 43 & & 47 & 28 & \\
\hline & $22.0 \%$ & $14.1 \%$ & & $14.6 \%$ & $23.9 \%$ & & $21.5 \%$ & $15.6 \%$ & \\
\hline \multicolumn{10}{|l|}{ Occupational status } \\
\hline Working $2+2$ & 134 & 111 & & 139 & 106 & & 122 & 123 & \\
\hline working & $56.8 \%$ & $68.1 \%$ & 003 & $63.5 \%$ & $58.9 \%$ & 350 & $55.7 \%$ & $68.3 \%$ & 000 \\
\hline Johbloc (houco wifo) & 102 & 52 & (003 & 80 & 74 & .350 & 97 & 57 & \\
\hline Jobless (house wire) & $43.2 \%$ & $31.9 \%$ & & $36.5 \%$ & $41.1 \%$ & & $44.3 \%$ & $31.7 \%$ & \\
\hline Occupation type & & & & & & & & & \\
\hline No occunation & 103 & 53 & & 81 & 75 & & 98 & 58 & \\
\hline No occupation & $43.6 \%$ & $32.5 \%$ & & $37.0 \%$ & $41.7 \%$ & & $44.7 \%$ & $32.2 \%$ & \\
\hline Officer (emnlovee) & 73 & 48 & & 70 & 51 & & 71 & 50 & \\
\hline Officer (employee) & $30.9 \%$ & $29.4 \%$ & & $32.0 \%$ & $28.3 \%$ & & $32.4 \%$ & $27.8 \%$ & \\
\hline Troder or deler & 9 & 27 & 000 & 9 & 27 & 000 & 9 & 27 & 000 \\
\hline Trader or dealer & $3.8 \%$ & $16.6 \%$ & .000 & $4.1 \%$ & $15.0 \%$ & .000 & $4.1 \%$ & $15.0 \%$ & .000 \\
\hline Skilled inh (nrofecsional) & 32 & 35 & & 40 & 27 & & 34 & 33 & \\
\hline Skilled job (professional) & $13.6 \%$ & $21.5 \%$ & & $18.3 \%$ & $15.0 \%$ & & $15.5 \%$ & $18.3 \%$ & \\
\hline Other ioh & 19 & 0 & & 19 & 0 & & 7 & 12 & \\
\hline Other job & $8.1 \%$ & $0.0 \%$ & & $8.7 \%$ & $0.0 \%$ & & $3.2 \%$ & $6.7 \%$ & \\
\hline Age at marriage & & & & & & & & & \\
\hline$<20$ vears & 121 & 89 & & 126 & 84 & & 116 & 94 & \\
\hline$<20$ years & $51.3 \%$ & $54.6 \%$ & 000 & $57.5 \%$ & $46.7 \%$ & 021 & $53.0 \%$ & $52.2 \%$ & 065 \\
\hline$>20$ yearc & 115 & 74 & .000 & 93 & 96 & .031 & 103 & 86 & .965 \\
\hline$\geq 20$ years & $48.7 \%$ & $45.4 \%$ & & $42.5 \%$ & $53.3 \%$ & & $47.0 \%$ & $47.8 \%$ & \\
\hline Marriage duration & & & & & & & & & \\
\hline$<5$ yeore & 180 & 113 & & 158 & 135 & & 169 & 124 & \\
\hline$<5$ years & $76.3 \%$ & $69.3 \%$ & OPA & $72.1 \%$ & $75.0 \%$ & 521 & $77.2 \%$ & $68.9 \%$ & 170 \\
\hline$>5$, & 56 & 50 & .004 & 61 & 45 & .521 & 50 & 56 & .170 \\
\hline$\geq 5$ years & $23.7 \%$ & $30.7 \%$ & & $27.9 \%$ & $25.0 \%$ & & $22.8 \%$ & $31.1 \%$ & \\
\hline Family income adequacy & & & & & & & & & \\
\hline A 1 wave not onoun & 127 & 75 & & 110 & 92 & & 112 & 90 & \\
\hline Always not enough & $53.8 \%$ & $46.0 \%$ & & $50.2 \%$ & $51.1 \%$ & & $51.1 \%$ & $50.0 \%$ & \\
\hline 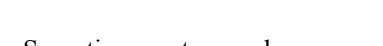 & 60 & 60 & & 51 & 69 & & 41 & 79 & \\
\hline Sometimes not enough & $25.4 \%$ & $36.8 \%$ & 000 & $23.3 \%$ & $38.3 \%$ & 000 & $18.7 \%$ & $43.9 \%$ & OPO \\
\hline Just enough (enough for living & 45 & 23 & . 000 & 54 & 14 & . 000 & 62 & 6 & .000 \\
\hline only) & $19.1 \%$ & $14.1 \%$ & & $24.7 \%$ & $7.8 \%$ & & $28.3 \%$ & $3.3 \%$ & \\
\hline Fnoul \& can cave from it & 4 & 5 & & 4 & 5 & & 4 & 5 & \\
\hline Enough \& can save from it & $1.7 \%$ & $3.1 \%$ & & $1.8 \%$ & $2.8 \%$ & & $1.8 \%$ & $2.8 \%$ & \\
\hline
\end{tabular}


Table 5. Relationship between fertility, obstetrical \& gynecological historyof the studied subjects and their psychological distress

\begin{tabular}{|c|c|c|c|c|c|c|c|c|c|}
\hline \multirow{2}{*}{ Variables } & \multicolumn{3}{|l|}{ Depression } & \multicolumn{3}{|l|}{ Anxiety } & \multicolumn{3}{|l|}{ Tension/Stress } \\
\hline & Non Morbid & Morbid & $P$ & Non Morbid & Morbid & $\boldsymbol{P}$ & Non Morbid & Morbid & $\boldsymbol{P}$ \\
\hline \multicolumn{10}{|l|}{ Menstrual disturbances } \\
\hline $\begin{array}{l}\text { Yes (irregular menstrual cycle) } \\
\text { No (regular menstrual cycle) }\end{array}$ & $\begin{array}{l}110 \\
46.6 \% \\
126 \\
53.4 \%\end{array}$ & $\begin{array}{l}107 \\
65.6 \% \\
56 \\
34.4 \%\end{array}$ & .000 & $\begin{array}{l}102 \\
46.6 \% \\
117 \\
53.4 \%\end{array}$ & $\begin{array}{l}115 \\
63.9 \% \\
65 \\
36.1 \%\end{array}$ & .001 & $\begin{array}{l}131 \\
58.8 \% \\
88 \\
40.2 \%\end{array}$ & $\begin{array}{l}86 \\
47.8 \% \\
94 \\
52.2 \%\end{array}$ & .055 \\
\hline \multicolumn{10}{|l|}{ Menstrual pain (dysmenorrhea) } \\
\hline $\begin{array}{l}\text { Yes } \\
\text { No }\end{array}$ & $\begin{array}{l}120 \\
50.8 \% \\
116 \\
49.2 \%\end{array}$ & $\begin{array}{l}97 \\
59.5 \% \\
66 \\
40.5 \%\end{array}$ & .000 & $\begin{array}{l}102 \\
46.6 \% \\
117 \\
53.4 \%\end{array}$ & $\begin{array}{l}115 \\
63.9 \% \\
65 \\
36.1 \%\end{array}$ & .001 & $\begin{array}{l}131 \\
59.8 \% \\
88 \\
40.2 \%\end{array}$ & $\begin{array}{l}86 \\
47.8 \% \\
94 \\
52.2 \%\end{array}$ & .055 \\
\hline \multicolumn{10}{|l|}{ Reproductive tract infection } \\
\hline 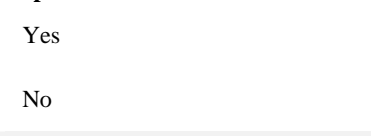 & $\begin{array}{l}46 \\
19.5 \% \\
190 \\
80.5 \%\end{array}$ & $\begin{array}{l}64 \\
39.3 \% \\
99 \\
60.7 \%\end{array}$ & .000 & $\begin{array}{l}32 \\
14.6 \% \\
187 \\
85.4 \%\end{array}$ & $\begin{array}{l}78 \\
43.3 \% \\
102 \\
56.7 \%\end{array}$ & .000 & $\begin{array}{l}50 \\
22.8 \% \\
169 \\
77.2 \%\end{array}$ & $\begin{array}{l}60 \\
33.3 \% \\
120 \\
66.7 \%\end{array}$ & .000 \\
\hline \multicolumn{10}{|l|}{ Type of reproductive tract infection } \\
\hline $\begin{array}{l}\text { No } \\
\text { Bacterial vaginosis, Trichomonas } \\
\text { vaginalis, and Candida albicans } \\
\text { Chlamydia infections }\end{array}$ & $\begin{array}{l}190 \\
80.5 \% \\
27 \\
11.4 \% \\
19 \\
8.1 \%\end{array}$ & $\begin{array}{l}99 \\
60.7 \% \\
43 \\
26.4 \% \\
21 \\
12.9 \%\end{array}$ & .000 & $\begin{array}{l}187 \\
85.4 \% \\
18 \\
8.2 \% \\
14 \\
6.4 \%\end{array}$ & $\begin{array}{l}102 \\
56.7 \% \\
52 \\
28.9 \% \\
26 \\
14.4 \%\end{array}$ & .000 & $\begin{array}{l}169 \\
77.02 \% \\
31 \\
14.2 \% \\
19 \\
8.8 \%\end{array}$ & $\begin{array}{l}120 \\
66.7 \% \\
39 \\
21.7 \% \\
21 \\
11.7 \%\end{array}$ & .000 \\
\hline \multicolumn{10}{|l|}{ Infertility type (history of pregnancy) } \\
\hline $\begin{array}{l}\text { Secondary (had pregnancy before) } \\
\text { Primary (never got pregnant) }\end{array}$ & $\begin{array}{l}24 \\
10.2 \% \\
212 \\
89.8 \%\end{array}$ & $\begin{array}{l}37 \\
22.7 \% \\
126 \\
77.3 \%\end{array}$ & .001 & $\begin{array}{l}15 \\
6.8 \% \\
204 \\
93.2 \%\end{array}$ & $\begin{array}{l}46 \\
25.6 \% \\
134 \\
74.4 \%\end{array}$ & 0.000 & $\begin{array}{l}38 \\
17.4 \\
181 \\
82.6\end{array}$ & $\begin{array}{l}23 \\
12.8 \% \\
157 \\
87.2 \%\end{array}$ & $\begin{array}{l}0.01 \\
6\end{array}$ \\
\hline Infertility duration & & & & & & & & & \\
\hline $\begin{array}{l}1 \text { year } \\
2 \text { years } \\
3 \text { years } \\
>3 \text { years }\end{array}$ & $\begin{array}{l}45 \\
19.1 \% \\
49 \\
20.8 \% \\
84 \\
35.6 \% \\
58 \\
24.6 \%\end{array}$ & $\begin{array}{l}39 \\
23.9 \% \\
23 \\
14.1 \% \\
40 \\
24.5 \% \\
61 \\
37.4 \%\end{array}$ & .000 & $\begin{array}{l}56 \\
25.6 \% \\
28 \\
12.8 \% \\
91 \\
41.6 \% \\
44 \\
20.1 \%\end{array}$ & $\begin{array}{l}28 \\
15.6 \% \\
44 \\
24.4 \% \\
33 \\
18.3 \% \\
75 \\
41.7 \%\end{array}$ & .000 & $\begin{array}{l}58 \\
26.5 \% \\
41 \\
18.7 \% \\
53 \\
24.2 \% \\
67 \\
30.6 \%\end{array}$ & $\begin{array}{l}26 \\
14.4 \% \\
31 \\
17.2 \% \\
71 \\
39.4 \% \\
52 \\
28.9 \%\end{array}$ & .002 \\
\hline History of miscarriage & & & & & & & & & \\
\hline 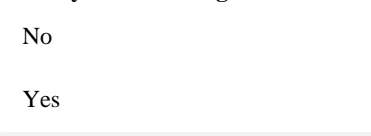 & $\begin{array}{l}222 \\
94.1 \% \\
14 \\
5.9 \%\end{array}$ & $\begin{array}{l}125 \\
76.7 \% \\
38 \\
23.3 \%\end{array}$ & .000 & $\begin{array}{l}206 \\
94.1 \% \\
13 \\
5.9 \%\end{array}$ & $\begin{array}{l}141 \\
78.3 \% \\
39 \\
21.7 \%\end{array}$ & .000 & $\begin{array}{l}202 \\
92.2 \% \\
17 \\
7.8 \%\end{array}$ & $\begin{array}{l}145 \\
80.6 \% \\
35 \\
19.4 \%\end{array}$ & .000 \\
\hline $\begin{array}{l}\text { Number of previous miscarriages } \\
0\end{array}$ & $\begin{array}{l}222 \\
94.1 \%\end{array}$ & $\begin{array}{l}125 \\
76.7 \%\end{array}$ & & $\begin{array}{l}206 \\
94.1 \%\end{array}$ & $\begin{array}{l}141 \\
78.3 \%\end{array}$ & & $\begin{array}{l}202 \\
92.2 \%\end{array}$ & $\begin{array}{l}145 \\
80.6 \%\end{array}$ & \\
\hline $\begin{array}{l}\text { Twice or more } \\
\text { Once }\end{array}$ & $\begin{array}{l}14 \\
5.9 \% \\
0 \\
0.0 \%\end{array}$ & $\begin{array}{l}31 \\
19 \% \\
7 \\
4.3 \%\end{array}$ & .000 & $\begin{array}{l}12 \\
5.4 \% \\
1 \\
0.5 \%\end{array}$ & $\begin{array}{l}33 \\
18.4 \% \\
6 \\
3.3 \%\end{array}$ & .000 & $\begin{array}{l}17 \\
7.8 \% \\
0 \\
0.0 \%\end{array}$ & $\begin{array}{l}28 \\
15.5 \% \\
7 \\
3.9 \%\end{array}$ & .000 \\
\hline Trials for assisted reproductive tecl & ogy (ART) & & & & & & & & \\
\hline Yes & $\begin{array}{l}28 \\
11.9 \% \\
208 \\
88.1 \%\end{array}$ & $\begin{array}{l}28 \\
17.2 \% \\
135 \\
82.8 \%\end{array}$ & .428 & $\begin{array}{l}28 \\
12.8 \% \\
191 \\
87.2 \%\end{array}$ & $\begin{array}{l}28 \\
15.6 \% \\
152 \\
84.4 \%\end{array}$ & .428 & $\begin{array}{l}11 \\
5 \% \\
208 \\
95 \%\end{array}$ & $\begin{array}{l}45 \\
25.0 \% \\
135 \\
75.0 \%\end{array}$ & .000 \\
\hline $\begin{array}{l}\text { Type of ART } \\
\text { Not applicable }\end{array}$ & $\begin{array}{l}213 \\
90.3 \%\end{array}$ & $\begin{array}{l}130 \\
79.8 \%\end{array}$ & & $\begin{array}{l}196 \\
89.5 \%\end{array}$ & $\begin{array}{l}147 \\
81.7 \%\end{array}$ & & $\begin{array}{l}208 \\
95 \%\end{array}$ & $\begin{array}{l}135 \\
75.0 \%\end{array}$ & \\
\hline $\begin{array}{l}\text { Artificial insemination(AI) or } \\
\text { Intrauterine insemination (IUI) }\end{array}$ & $\begin{array}{l}5 \\
2.1 \%\end{array}$ & $\begin{array}{l}17 \\
10.4 \%\end{array}$ & & $\begin{array}{l}5 \\
2.3 \%\end{array}$ & $\begin{array}{l}17 \\
9.4 \%\end{array}$ & & $\begin{array}{l}5 \\
2.3 \%\end{array}$ & $\begin{array}{l}17 \\
9.4 \%\end{array}$ & \\
\hline In Vitro Fertilization (IVF) & $\begin{array}{l}12 \\
5.1 \%\end{array}$ & $\begin{array}{l}13 \\
8.0 \%\end{array}$ & & $\begin{array}{l}12 \\
5.5 \%\end{array}$ & $\begin{array}{l}13 \\
7.2 \%\end{array}$ & & $\begin{array}{l}0 \\
0.0\end{array}$ & $\begin{array}{l}25 \\
13.9 \%\end{array}$ & \\
\hline $\begin{array}{l}\text { Intra Cytoplasmic Sperm Injection } \\
\text { (ICSI) }\end{array}$ & $\begin{array}{l}6 \\
2.5 \%\end{array}$ & $\begin{array}{l}3 \\
1.8 \%\end{array}$ & .011 & $\begin{array}{l}6 \\
2.7 \%\end{array}$ & $\begin{array}{l}3 \\
1.7 \%\end{array}$ & .012 & $\begin{array}{l}6 \\
2.7 \%\end{array}$ & $\begin{array}{l}3 \\
1.7 \%\end{array}$ & .000 \\
\hline $\begin{array}{l}\text { Gamete Intrafallopian Transfer } \\
\text { (GIFT) }\end{array}$ & $\begin{array}{l}0 \\
0.0\end{array}$ & $\begin{array}{l}0 \\
0.0\end{array}$ & & $\begin{array}{l}0 \\
0.0\end{array}$ & $\begin{array}{l}0 \\
0.0\end{array}$ & & $\begin{array}{l}0 \\
0.0\end{array}$ & $\begin{array}{l}0 \\
0.0\end{array}$ & \\
\hline $\begin{array}{l}\text { Zygote Intrafallopian Transfer } \\
\text { (ZIFT) }\end{array}$ & $\begin{array}{l}0 \\
0.0\end{array}$ & $\begin{array}{l}0 \\
0.0\end{array}$ & & $\begin{array}{l}0 \\
0.0\end{array}$ & $\begin{array}{l}0 \\
0.0\end{array}$ & & $\begin{array}{l}0 \\
0.0\end{array}$ & $\begin{array}{l}0 \\
0.0\end{array}$ & \\
\hline Tubal Embryo Transfer (TET) & $\begin{array}{l}0 \\
0.0\end{array}$ & $\begin{array}{l}0 \\
0.0\end{array}$ & & $\begin{array}{l}0 \\
0.0\end{array}$ & $\begin{array}{l}0 \\
0.0\end{array}$ & & $\begin{array}{l}0 \\
0.0\end{array}$ & $\begin{array}{l}0 \\
0.0\end{array}$ & \\
\hline
\end{tabular}


In this section, we discussed findings in two areas related to these core elements: the sociodemographic \& special characteristics, prevalence and associate the level of psychological distress (tension/anxiety/depression) among women who were infertile in Northern Upper Egypt. We also review the literature on gynecological implications as well as reproductive tract infections among infertile women and co-relate the findings with their psychological distress.

Firstly, the sociodemographic, special characteristics, prevalence and statistical association of psychological status amongst those upper Egyptian women who were infertile in relation to their sociodemographic and special variables in regards to psychological distress (depression, anxiety and tension).

Psychological factors play a main role in inducing infertility, whereas these factors may be considered as the result of infertility, as well. ${ }^{[15]}$ When the psychological implications related to human infertility have been extensively studied by Franco (2003), the most frequent possible disturbances were depression, anxiety, strong psychological tension, crisis with the marital relationship and divorce. ${ }^{[27]}$ A similar pattern was observed regarding psychological distress. It was noticed, from the findings of the present study, that more than one-third of the studied subjects was having a morbid degree of depression, roughly one-half of them were having morbid anxiety and tension. This result had a serious indicator of the infertile woman's psychological health status, this indicated that she need to review psychological team beside obstetric and gynecological ones to receive effective counseling and treatment for her case. This finding was in accordance with Upkong (2006) who found that the prevalence of psychiatric morbidity was $46.4 \%$ in the infertile women, $42.9 \%$ and $37.5 \%$ were cases of depression and anxiety, respectively. ${ }^{[44]}$ Moreover, Freeman \& his colleagues had mentioned that roughly half of the sample in their study rated infertility as the most stressful experience of their lifetime. In summation, they found that $16 \%$ of their studied subjects had significant psychological distress, including a high degree of depression and somatization. ${ }^{[45]}$ Seyyedeh et al. (2013) added that $86 \%$ of infertile couples experience depression \& about $40 \%$ experience anxiety. ${ }^{[46]}$ In addition, the results of Kishanth (2014) indicates that 57\% infertile women were having a severe degree of anxiety. ${ }^{[4]}$

In the same line, the results of Al-Homaidan (2011) in Kingdom Saudi Arabia showed that $53.8 \%$ of the Saudi infertile women had depression. Mean BDI score between fertile and infertile women was significantly different $(p<.001)$. Infertile women were found to be more liable to severe depression $(p=.014) .{ }^{[43]}$
An Iranian study displayed that depression is more common among infertile couples than fertile ones $(p<.015){ }^{[47]}$ Nelson et al. used the Center for Epidemiological Studies Depression Scale (CES-D) for depression and found that $19 \%$ \& $13 \%$ of infertile women, respectively, had moderate and severe depression. ${ }^{[48]}$ Moreover, Drosdzol et al. found that $35.4 \%$ infertile women scored above the cutoff for severe symptoms of depression. ${ }^{[49]}$

According to the current study findings, it was revealed that the infertile women exhibited higher statistically significant between sociodemographic variables (age, level of educational, occupational status, occupation type, age at marriage, and family income adequacy) and Psychopathology in all parameters in the form of tension, anxiety, depression. Our findings reinforce the need for gynecologists and professionals as well as health care sectors to look for psychosocial distress in women undergoing infertility treatment. Psychological interventions and improvements in the organization of care are essential to positively impact on outcome during treatment in this group of women. These findings are not consistent with Kishanth et al. (2014) who studied the degree of anxiety among women with infertility problems, at the Pondicherry city hospital and found that there was no significant association between the level of anxiety among women with infertility and the demographic variables. ${ }^{[4]}$ In the same line Upkong (2006), who studied the mental health of infertile women in Nigeria, stated that there were no significant differences when the sociodemographic parameters were compared in terms of age, educational level and employment status. ${ }^{[44]}$

Previous studies illustrate that women ages correlate well with fecundity. Even when they have regular ovulated, treatment success declines sharply after age thirty-seven. This reflected that the older the woman, the less chance to conceive and bear children. ${ }^{[50]}$ The result of the present study showed that the group aged 25-40 years display highest percentage (70.2\%) of the study subjects. As well, it shows that the same group of women was at risk of developing psychological distress. A highly statistically significant difference was observed between women's psychological implication and their ages as older women significantly have a worse psychological condition. It can conclude that higher distress in older women can be related to their worries about the fecundity. While young ones have social support as they are still young and have more chance and period for treatment and bear children. These findings were in agreement with the result of Kishanth et al. (2014). ${ }^{[4]}$ But they were opposing the results of the study done by Rashidi et al. (2008) who found that the younger subjects had higher anxiety compared to older ones. ${ }^{[51]}$ 
Education for Upper Egyptian women had improved in recent decades. According to the present study findings, the majority of the study subjects had a satisfactory level of education. The study illustrated that there was a statistically significant difference in psychological status amongst those upper Egyptian women who were infertile in regards to their educational level. These findings are congruent with the result of Kishanth et al. (2014), but the results of Beutel's (1999) study were not similar. He denotes that educational level has no significant relation to anxiety and/or depression. ${ }^{[4,52]}$

Concerning the occupational status, the results of the current study revealed that, $61.4 \%$ of the studied subjects were working. The employed had the highest prevalence of depression, anxiety and tension when compared with the unemployed ones. This result may be because the woman economically helps her family and tries to earn money to provide food for them. In this case, the woman has much psychological distress related to the burden of her job added to infertility condition. However, work ensures the independence and financial security; it exhausts the women and exposes them to unfavorable social scrutiny which may lead to psychological problems. However, this result was in line with the study done by Noorbala et al. (1999) which found that the rate of psychological disorder was higher among working women. ${ }^{53]}$ It was contradicted what Upkong (2006) and Ramezanzadeh et al. (2004) found in their study. They found that depression and/or anxiety were observed more in housewives than in outside employees. ${ }^{[44,54]}$ Moreover, Boivin (2003) found that psychological disorders being more common in housewives than in working ones. ${ }^{[55]}$ However, a statistically significant difference was observed among participants working group in relation to depression $(p=.003)$ and tension $(p=.000)$, an office employee in the current study had highest psychological complain in the dimensions of depression $(p=.000)$, anxiety $(p=.000)$ and tension $(p=$ $.000)$ than other jobs. This may be attributed to that an office employee may liable to suffer extra stress \& tension rather than other jobs.

In relation to family income, it was obvious from the results of the present study that, the majority of the study subjects did not have enough family income while merely $2.3 \%$ of them had enough family income and can save from it. The results had also revealed a high statistic significant relationship between women's psychological status and their family income adequacy. It was not surprising to find that, Psychological distress was more prevalent among poor infertile women than rich ones. This would affect badly the women's health. Moreover, poverty might increase the burden on women caring for many individuals and striving hard for a living. These results were supported by the fourth world

Published by Sciedu Press conference (1995) which denoted that statistics about women and poverty were all too familiar, where women were the majority of 1.3 billion people living in extreme poverty. ${ }^{[56]}$

As regards age at marriage of the studied subjects, the results of the present study presented that more than half of them $(52.6 \%)$ married at age less than 20 years. The mean age at marriage was $19.74 \pm 1.61$. Furthermore, a significant difference was noticed between women's age at marriage and their psychological implication (depression; $p=.000$ ) and (anxiety; $p=.031$ ). This might be ascribable to the fact that day by day life enhances women's experience and improves their knowledge. Early marriage could have a negative effect on the women's education; this had exposed these women not only to ignorance of their condition but also to complications. Early marriage has hindered women to complete their education and to get an appropriate job and had become financially dependent on their kin. Therefore, teen women were more likely to live in poverty than women who were in delayed marriage age. Moreover delaying age at marriage was a key to improving women's status and may be a way of increasing their leverages in the decision-making process. This was in accordance with Chou (2004) who stated that, the impact of childlessness on psychological well-being among elderly Chinese is more robust than that found in older Americans. ${ }^{[1]}$

Regarding the duration of marriage among infertile women, the present study revealed that $73.4 \%$ of the study subjects were less than 5 years while $26.6 \%$ of them were more than 5 years. The mean duration of the marriage was $3.83 \pm 2.21$. In addition, it was found that $69.3 \%$ of the study subjects, who their duration of marriage less than five years, had morbid symptoms of depression. This may be attributed to, in Islamic and eastern countries, family status, especially childbearing is very important and valuable. Moreover, infertility is a main social onus for women in Upper Egypt, who are required to have children early in their marital life. Childlessness resulted in a social stigmatization of infertile women and may place them at risk of serious social consequences. Women without kids often feel incomplete and this results in blame and pressure from their relatives, families, neighbors, and society, as well as threat her marriage life; therefore contributing to psychological problems.

Nonetheless, there was no statistically significant difference in psychological status (except in depression $p=.004$ ) amongst those infertile women in relation to their duration of the marriage, the results showed decreasing psychological distress percentage by increasing lengthening of marriage duration. It can conclude that lower distress in couples who experienced a long period of marriage may also be influenced by their norms, beliefs, and religion. In Islam, the religious 
and cultural perspectives of infertility could be challenging for clients. The Islamic religion and the faith to believe that most things come from Allah and experience acceptance of God's will by utterances like "Insha Allah", which means God Willing, and "Alhamdu Li-La" meaning thanks be to God. Also, infertility had been addressed in the Quran as "to Allah belongs the kingdom of heavens and the earth", "He" creates whatever He pleases, He gives the daughters to whom He pleases and gives sons to whom He pleases and "He" gives both sons and daughters and make burden whom He wills (Holy Quran). An infertile couple might be consoled because Allah wishes for them to be childless These results are consistent with Kishanth et al. (2014) who found that $40 \%$ of depressed infertile women, their duration of marriage was between 1-3 years and $13.3 \%$ were above 10 years. ${ }^{[4]}$

Secondly, the gynecological variable as well as reproductive tract infections prevalence $\&$ statistical association of psychological status amongst those upper Egyptian women who were infertile in relation to their gynecological issues in regards to psychological distress (depression, anxiety and tension).

Regarding age at menarche \& menstrual disturbance, it is evident that the mean age at menarche of the study subjects was $15.40 \pm 2.20$ years and more than half $(54.4 \%)$ of them had an irregular menstrual cycle. This result is in agreement with Kishanth et al. (2014) who found that $36.6 \%$ of infertile women in their study attained menarche at age 13-15 years $\& 13.3 \%$ at age $16-18$ years. They added that $56.6 \%$ women had an irregular menstrual cycle. ${ }^{[4]}$ According to the present study findings, it was found that $65.6 \%, 63.9 \%$ \& $47.8 \%$ of women who had irregular menstrual cycle had a morbid level of depression, anxiety \& tension respectively. A statistically significant difference was observed between women's menstrual cycle disturbances and their psychological distress.

Dysmenorrhea is a common problem in women of reproductive age. The main risk factor for dysmenorrhea is nulliparity. ${ }^{[33]}$ It was noticed, from the findings of the present study, that more than half of the studied subjects (54.4\%) had dysmenorrhea. This result is congruent with the results of Kishanth et al. (2014) who reported that $56.6 \%$ infertile women had dysmenorrhea ${ }^{[4]}$ Moreover, this study demonstrates a statistically significant impact of dysmenorrhea among infertile women on their psychological status. This is supported by Linda (2005) who stated that the depression, anxiety \& disruption of social support networks have been associated with menstrual pain. ${ }^{[33]}$

RTI infection is mainly acquired as a consequence of inadequate health care, results in increased rates of secondary infertility. In developing societies, the high prevalence of RTI infection and childlessness are often highly stigmatized and leads to profound social suffering for infertile women in particular. ${ }^{[3]}$ In some societies, particularly in rural areas, female are common visitors to the RTI clinic. ${ }^{[57]}$ At the time of worldwide financial crises, information on reproductive morbidity is essential to ensure the most appropriate allocation of existing resources and the planning of cost-effective health care strategies. ${ }^{[10]}$ The present study was also concerned about assessing the reproductive tract infections among infertile women. It was noticed that the more than quarter (27.6\%) of the studied subjects had reproductive tract infections. This result reflects the impact of culture among Egyptian women in Upper Egypt, particularly in rural regions, which often term to these infections as minor condition and pay little attention to these nuisances and thus absolutely refuse gynecologist counseling for female reproductive system. They likewise had a lack of knowledge regarding the scientific information about proper management $\&$ hygienic care of reproductive tract infection. This result is in line with Kishanth et al. (2014) who found that the $27.6 \%$ of their studied subjects had reproductive tract infections. ${ }^{[4]}$ On the other hand, it was surprisingly to find that women with infertility and did not had reproductive tract infection experience higher rates of morbid psychological distress (depression, $60.7 \%$ ), (anxiety, 56.7\%), (tension, 66.7\%) compared with they had reproductive tract infection counterparts (depression, 39.3\%), (anxiety, 43.3\%), (tension, 33.3\%). This result might be due to that, when an infertile woman knows the cause and undergoing treatment she will have the hope in motherhood and to get pregnant, which result in decreased rates and level of psychological distress. A highly significant association was found among infertile women having symptoms of reproductive tract infections with their tension, anxiety and depression $(p=.000)$; similar results were found in the studies carried out by other researchers. ${ }^{[58-60]}$

Concerning types of reproductive tract infection, it was noticed that $17.5 \%$ of the study subjects had bacterial vaginosis, Trichomonas vaginalis \& Candida albicans while $10.0 \%$ of them had Chlamydia infections. Moreover, it was observed that $21.7 \%, 28.9 \% \& 26.4 \%$ of infertile women who infected by Bacterial vaginosis, Trichomonas vaginalis, and Candida albicans had a morbid level of tension, anxiety and depression, respectively. In addition, $12.9 \%, 14.4 \% \& 11.7 \%$ of study subjects who infected by Chlamydia infections had a morbid degree of depression, anxiety and, tension respectively. Moreover, the results of the present study revealed that Bacterial vaginosis, Trichomonas vaginalis, and Candida albicans infections recorded higher percentage in both morbidity and non morbid psychological distress than Chlamydia 
infections. This may be due to the mode of transmission of bacterial Vaginosis, Trichomonas vaginalis, and Candida albicans infections are more common and more easily than Chlamydia infections as by contaminated clothes or even poor hygiene. Novy et al. (2015) stated that C. Trachomatis salpingitis is the most common in infected women after induced abortion or vaginal delivery. The organism presumably ascends from the cervix, usually producing mild or no symptoms two weeks. Salpingitis occurs in $15 \%$ of women with C. Trachomatis who undergo an induced abortion. Between one-fourth and two-thirds of women with tubal infertility have been pregnant before becoming infertile. Because $\mathrm{C}$. Trachomatis is usually present in $5 \%$ to $10 \%$ of pregnant women, the impact of Chlamydia salpingitis after pregnancy and subsequent infertility may be substantial. ${ }^{[13]}$ A highly significant association was found among infertile women's types of reproductive tract infections with their tension, anxiety and depression $(P=.000)$.

Concerning the type of infertility, it was noticed that the majority (84.7\%) of the study subjects had primary infertility while $15.3 \%$ of them had secondary infertility. Moreover, women suffering from primary infertility scored higher on all outcome morbid measures of depression, anxiety \& tension $(77.3 \%, 74.4 \%, 87.2 \%)$, respectively, than secondary infertility $(22.7 \%, 25.6 \%, 12.8 \%)$ as Women who have had children suffered less from than women with no children at all as the first ones did not deprive at all from children. In addition, a significant difference was observed between women's psychological implication "stress/anxiety/depression" and their type of infertility ( $p=.016, .000, .001)$, respectively. These findings are consistent with Upkong D. ${ }^{[44]}$

There is a trend of increasing psychological distress with the lengthening of infertility time. Long lasting and fruitless infertility treatment intensifies stress \& psychopathologic symptoms. The current study findings showed that the mean infertility duration was $3.09 \pm 2.34$. It was noticed that women with short period (less than three years) of infertility suffered less and had lower psychological distress than those with a long period (three or more than three years) of infertility. These findings contradict with the result of Kee et al. (2000) who stated that based on depression scales, infertile patients who had infertility for an intermediate to a long time showed less symptoms than those who are in their first stage of their problem, ${ }^{[61]}$ while in agreement with the findings of other studies as Al-Homaidan (2011) and Ramezanzadeh et al. (2004) who showed that psychological distress in infertile women increase with time \& depression peaks between the second and third year of infertility and does not come back to normal range until after six years of infertility. ${ }^{[3,54]} \mathrm{A}$ longer time period of infertility and repeated, referring to

Published by Sciedu Press the physicians, infertility would gradually shift to a chronic problem; thus confronting this problem, the infertile women would have experienced monthly cycles of hope and hopelessness, their stress, and depression severity would decrease but would never disappear. ${ }^{[62,63]}$ It was shown that the first three years, depression is at its lowest limit and after four years it becomes worse. It seems that our results are different compared to other countries. It may show that having a child is very important for our people, especially our women, therefore, women show higher and longer emotional reactions and psychological symptoms lasts longer in comparison to other countries. ${ }^{[43]}$ Statistically, significant associations were found, in the present study, between infertility duration and degree of depression/anxiety/tension $(p=.000, .000$, .002 ), respectively. This result disagreed with the result of a study was done by Rashidi et al. (2008) which found that mental quality of life has no relation to infertility duration. ${ }^{[51]}$

Concerning the history of abortion, it was obvious from the results of the present study that $13.0 \%$ of the study subjects had previous aborted, $11.3 \%$ had aborted once only while only $1.8 \%$ had aborted twice or more. The previously aborted women had the lowest prevalence of depression, anxiety and tension when compared with the non-aborted ones $(p=.000)$. This result may be due to the fact that if women get pregnant before, even this pregnancy ended by abortion, this mean that she is not sterile and she will have the hope to get pregnant at any time. Moreover, the women with recurrent abortion were having the highest prevalence of psychological distress compared with those who aborted once only. It was not surprising to find this result as the women who had experienced a previous recurrent abortion may be convinced that the infertility is a result of those events. This may lead them to guilty feeling and questioning themselves regarding their worthiness as a wife and a potential mother. A woman who had an elective abortion and fears it may have caused her infertility may become obsessed with blaming herself for her infertility. This study demonstrates a statistically significant impact of the number of previous miscarriage on psychological distress (depression/anxiety/tension) among infertile women $p=(.000, .000, .000)$ respectively. This result is congruent with the result of Upkong (2006) who reported that, the infertile women were however much more likely to have had a history of spontaneous/induced abortions, and this was significant $\left(\chi^{2}=21.88, P=.001\right)$. Psychological outcomes of the infertility were recorded in $46.4 \%$ of the subjects with infertility. The BDI detected depression in $42.9 \%$ of the infertility subjects. There were $37.5 \%$ cases of anxiety in the index group. ${ }^{[4]}$

The causal role of psychological disturbances in the development of infertility treatment is still a matter of debate. 
A growing number of research have studied the impact of infertility treatment at different levels, with most concentrating on the impact of IVF trials. The present study was also concerned about evaluating infertility treatment. It was noticed that $14.0 \%$ of the studied subjects tried to get pregnant through medical intervention and ART; (5.5\% by AI, 6.3\% by IVF, and only $2.3 \%$ by ICSI). This may be due to the low educated $\&$ housewives may be attributed the causes of their infertility to supernatural causes, such as witchcraft, evil spirits, and God's retribution. Furthermore, Egyptian women especially who live in Upper Egypt are still sticking to their old traditional and ancient pattern of life especially the inherited primitive prescriptions for treatment of infertility. Faith and traditional healers were the first option for the treatment of infertility among illiterate and jobless women. Moreover, it was obvious from the results of the present study that only $2.3 \%$ of the study subjects who were having enough family income and can save from it so they can pay for medical intervention. The results also illustrated that the incidence of psychological distress among infertile women presenting for assisted reproduction is significantly higher than other ones who not presenting for treatment. This result was not amazing since all of us recognize the high price of follow-up and treatment of infertility and how much is expensive. This study demonstrates a statistically significant impact on the type of medical intervention on psychological distress (depression/anxiety/tension) among infertile women $p=(.011$, $.012, .000)$ respectively. This result is congruent with the results of a number of studies. ${ }^{[18,26]}$

Soltani (2014) added that the process of ART itself is also associated with increased levels of anxiety/depression/stress. After the abortive treatment of zygotic embryos in IVF, 25\% of women become depressed. Treatment of infertility is a severe stresses process, and many women undergoing fertility treatment experience significant emotional distress. ${ }^{[15]}$ Klock (2011) added that women reported more depression before and after infertility treatment. Surveyed couples after they had completed one cycle of IVF and, as an indirect measure of how stressful the procedure was, asked couples if they would undergo IVF again. The result was that $38 \%$ of the couples reported that they would not undergo IVF again because it was too expensive, the success rate was too low, and they were unwilling to undergo the emotional pain of the procedure. In addition, $18 \%$ reported that infertility had a negative impact on their marriage and $66 \%$ of women reported that they had become depressed after the procedure, with $13 \%$ of the women reporting that they had suicidal ideation after an unsuccessful IVF. ${ }^{[2]}$

Finally, Whereas cost or refusal of physicians to continue treatment have been cited as reasons for discontinuing treat- ment, recent research suggests that a significant number of dropouts are due to psychological factors. ${ }^{[64]}$ The outcome of infertility treatment may also be influenced by psychological factors. A number of studies have examined stress and mood state as predictors of outcome in assisted reproduction. The bulk of these studies supports the theory that distress is linked with lower pregnancy rates among women pursuing infertility treatment. ${ }^{[26]}$

\section{Conclusion}

A range of existing studies suggests that infertility and psychological issues are related in a complex way. This study helps the nursing researchers to advance knowledge regarding psychological distress experienced by women with infertility. In conclusion, there is a statistically significant association between psychological status amongst those Northern Upper Egyptian women who were infertile in relation to their sociodemographic, special variables, gynecological impairments as well as reproductive tract infections and in regards to depression, anxiety and tension.

\section{Recommendation}

Based on the results of the study, the following recommendations can be derived:

(1) The upper Egyptian infertile women are vulnerable to psychological distress. Pressure from family to get pregnant is a significant contributor to psychological disorder and requires psychological support. This indicates the incorporate and appropriateness of referring these women for psychological health screening and evaluation during and after treatment for infertility and manage concomitantly.

(2) Infertility is associated with high levels of psychological morbidity. Our findings reinforce the need for gynecologist \& health care professionals to look for psychosocial distress in women undergoing fertility treatment.

(3) Accurate health education about reproductive and gynecological morbidity would reduce embarrassment reproductive tract infections and the stigma of infertility. Health services \& health care providers should be more accessible so that women feel more comfortable in seeking treatment and not deterred by concerned over privacy and confidentiality.

(4) Stress management programs have been set up to reduce psychological distress which is a common part of the life of people struggling with infertility. Programs successful in dealing with infertility in Upper Egypt need to include the establishment of a communitybased intervention strategy to educate people about infertility and give guidelines for proper treatment. 
(5) Nurses as a counselor should provide counseling, guidance, and have the responsibilities to teach such techniques among women with infertility as it offers a great challenge in today's world. Maternity and gynecologic health nurses should be fitted with the appropriate sciences, knowledge and skills that were necessary to help people adjust to the daily problems \& related difficulties. Also, possible, we need for additional \& continuous training for nurses who are employed in the fertility settings, to make them more aware about the psychological \& social domains and their impacts on clients.

\section{CONFliCts OF INTEREST Disclosure}

The authors declare that there is no conflict of interest.

\section{REFERENCES}

[1] Chou K, Chi I. Childlessness and psychological well-being in Chinese older adults. Int J Geriatr Psychiatry. 2004; 19(5): 449-57. PMid:15156546 http://dx.doi.org/10.1002/gps.1111

[2] Klock S. Psychological Issues Related to fertility. The Global Library of Women's Medicine. 2011.

[3] Nachtigall R. International disparities in access to infertility services. Fertility and Sterility. 2006; 85(4): 871-875. PMid:16580367 http://dx.doi.org/10.1016/j.fertnstert.2005.08.066

[4] Kishanth O, Prema K, Susila C. Level of anxiety among women with infertility problems, at Pondicherry city hospital, Puducherry - A Descriptive study. International Journal of Comprehensive Nursing. 2014; 1(1).

[5] Marcia C, Pasquale P. Infertility around the globe: new thinking on gender, reproductive technologies and global movements in the 21st century. Human Reproductive update. 2015.

[6] Ardekani A, Chaharsoughi S. Infertility and stress. Int J Fertil Steril. 2010; 4(Suppl 1): 48.

[7] Human Fertilization \& Embryology Authority (HFEA, 2007). HFEA, 182. Code of practice. 2003.

[8] Akhondi M. Iranian society of embryology and reproductive biology (ISERB). 2012. Available from: http://www. iserb.ir

[9] Sheldon M, Cronin J, Goetze L, et al. Defining Postpartum Uterine Disease and the Mechanisms of Infection and Immunity in the Female Reproductive Tract in Cattle. Biol Reprod. 2009; 81(6): 10251032. PMid:19439727 http://dx.doi.org/10.1095/biolrep rod.109. 077370

[10] Komal T, Prakash M, Pukur T, et al. Fertility Profile, Anxiety, Depression of Married Women and Its Association with Reproductive Tract Infections in the Rural Area of Surendranagar District. Sch. J. App. Med. 2014; 2(1A): 104-108.

[11] National reproductive tract infections (RTI) policy guidelines (GHS/HRU/HORIZONS/USAID and WHO, 2003).

[12] Novy M, Eschenbach D, Witkin S. Infections as a Cause of Infertility. The Global Library of Women's Medicine. 2008.

[13] Weissman W. Mind/body interferences on infertility. European Soci Hum Reprod and Embryo. 2003; 18(10): 2073-2078.

[14] Akker O. Coping, Quality of Life and Psychological Symptoms in Three Groups of Sub-Fertile Women. Patient Educ Couns. 2005; 57: 183-189. PMid:15911191 http://dx.doi.org/10.1016/j.pec .2004 .05 .012

[15] Soltani M, Shairi M, Roshan R, et al. The impact of emotionally focused therapy on emotional distress in infertile couples. International Journal of Fertility \& Sterility. 2014; 7(4): 337-44. PMid:24520504

[16] Volgsten H, Shoog S, Ekselius L, et al. Prevalence of psychiatric disorders in infertile women and men undergoing in vitro fertilization. Hum Reprod. 2008; 23: 2056-2063. PMid:18583334 http://dx.doi.org/10.1093/humrep/den154

[17] Verhaak C, Smeenk J, Nahuis M, et al. Long term psychological adjustment to IVF/ICSI treatment in women. Hum Reprod. 2007; 22: 305-308. PMid:16973721 http://dx.doi.org/10.1093/humre $\mathrm{p} / \mathrm{del} 355$

[18] Chen T, Chang S, Tsai C, et al. Prevalence of depressive and anxiety disorders in an assisted reproductive technique clinic. Hum Reprod. 2004; 19(10): 2313-2318. PMid:15242992 http://dx.doi.org/1 $0.1093 /$ humrep/deh414

[19] Eysenck M. Anxiety and Cognition: A Unified Theory. Psychology Press; 2014. PMid:24528147

[20] Aydin L, Yucel S. Anxiety and comfort levels of nursing students Journal of Nursing Education and Practice. 2014; 4(8): 179-187. http://dx.doi.org/10.5430/jnep.v4n8p179

[21] Elder R, Evans K, Nizette D. Psychiatric and mental health nursing. 2nd ed. Sydney: Elsevier; 2009.

[22] Domar D. Depression and Infertility: Treatment Considerations. Published in Resolve for the journey and beyond. Spring 2014.

[23] Braverman A. Battling the self blame of infertility. Monitor on psychology (APA). 2006; 37 (8): 120-132.

[24] England M. Review of Psychotherapy for the advanced practice psychiatric nurse. Perspectives in Psychiatric Care. 2008; 44(3): 219-220. http://dx.doi.org/10.1111/j.1744-6163.2008.00179.x

[25] Webster S, Gallagher S, Brown P, et al. The perceptions of nurses in their management of patients experiencing anxiety. Journal of Nursing Education and Practice. 2012; 2(3): 38-45. http://dx.d oi.org/10.5430/jnep.v2n3p38

[26] MGH Center for Women's Mental Health. Women's Mental Health Across the Life Cycle. "Fertility and Mental Health"; Stress, Depression and Anxiety Associated with Infertility and Its Treatment. Harvard Medical School. http://womensmentalhealth.org/

[27] Franco J. Ethics, legal, social, counseling: Comparison of the psychological evaluation test and classical psychoanalysis in infertile women. Reproductive BioMedicine online. 2003; 8(1): 8-13. http://dx.doi.org/10.1016/S1472-6483(10)60492-0

[28] Katherine E, Williams, Wendy K, et al. Mood disorders and fertility in women: A critical review of the literature and implications for future research. Human Reproduction Update. 2007; 13(6): 607616. PMid:17895237 http://dx.doi .org/10.1093/humupd/dm m019

[29] Paolo T. Clinical Management of Male Infertility: Prevalence, Definition, and Classification of Infertility. Springer; 2015; 5-11.

[30] McKinney E, James S, Murray S, et al. Maternal Child Nursing. Saunders: Elsevier, Canada. 2009; 202. 
[31] Wheaton B. The twain meet: distress, disorder and the continuing conundrum of categories (comment on Horwitz). Health. 2007;11: 303-319. http://dx.doi.org/10.1177/1363459307077545

[32] Mirowsky J, CE. Ross. Selecting outcomes for the sociology of mental health: Issues of measurements and dimensionality. J Heal Soci Behavi. 2002; 43: 152-170. PMid:12096697 http://dx.doi.org $/ 10.2307 / 3090194$

[33] Linda F. Dysmenorrhea. American Family Physician. 2005; 71(2): 285-291.

[34] http://www.medilexicon.com/medicaldictionary

[35] http://www.pamf.org/fertility/treatments/ivf/

[36] Atlantic Assisted Reproductive Therapies Suite 213,1535 Dresden Row, Halifax, NS B3J 3T1 (902) 404-8600, AART FRM Clin066 20100503 Infertility Questionnaire (Female).

[37] Sayed Y. Depression between definition and the symptoms and diagnosis. 2008. http://www.maktoobblog.com/sayed_yusuf 00? post $=22924$

[38] Fahmy M, Ghally M. http://www.acofps.com/up//uploads/. ../acofps-334e7672fe.

[39] Taylor R, Lovibond PF, Nicholas MK, et al. The utility of somatic items in the assessment of depression in patients with chronic pain: A comparison of the Zung Self-Rating Depression Scale and the Depression Anxiety Stress Scales in chronic pain and clinical and community samples. Clin J Pain. 2005; 21: 91-100. http://dx.doi.org/10.1097/00002508-200501000-00011

[40] Lovibond P, Lovibond S. Manual for the Depression Anxiety Stress Scales (DASS); 2nd ed. Psychology Foundation, Sydney. 1995. Available from: http://www2 . psy. unsw.edu.au/dass/over.htm

[41] Perry S, Hockenberry M, Lowdermilk D, et al. Maternal Child Nursing Care, 4th ed. Canada: Mosby; 2010; 129. PMid:21687776

[42] Cousineau T, Domar A. Psychological impact of infertility. Clinical Obstetrics \& Gynecology. 2007; 21(2): 293-308. http://dx.doi .org/10.1016/j . bpobgyn. 2006.12.003

[43] Al-Homaidan H. Depression among Women with Primary Infertility attending an Infertility Clinic in Riyadh, Kingdom of Saudi Arabia: Rate, Severity, and Contributing Factors. Int J Health Sci (Qassim). 2011; 5(2): 108-115.

[44] Upkong D, Orji E. Mental health of infertile women in Nigeria. 2006 Winter; 17(4): 259-65.

[45] Freeman E, Boxer A, Rickels K, et al. Psychological evaluation and support in a program of in vitro fertilization and embryo transfer. Fertil Steril. 1985; 43: 48-53. PMid:3965315

[46] Seyyedeh Z, et al. Prevalence of Depression among Infertile Couples in Iran: A Meta-Analysis Study. 2013. Available from: http: //www.ncbi.nlm.nih.gov/pmc/articles/PMC3684453/

[47] Ashkani H, Akbari A, Heydari S. Epidemiology of depression among infertile and fertile couples in Shiraz, Southern Iran. Indian J Med Sci. 2006; 60: 399-406. http://dx. doi.org/10.4103/0019-5 359.27670

[48] Nelson C, Naughton C, Ohebshalom M, et al. Sexual Function and Quality of Life in The Male Partner of Infertile Couples: Prevalence and Correlates of Dysfunction. J Urol. 2008; 179: 10561059. PMid: $18206931 \mathrm{http}: / / \mathrm{dx}$.doi.org/10.1016/j.juro. 2007.10 .069
[49] Drosdzol A, Skrzypulec V. Depression and anxiety among Polish infertile couples-an evaluative prevalence study. J Psychosom Obstet Gynaecol. 2009; 30(1): 11-20. PMid:19308778 http://dx.doi.o $\mathrm{rg} / 10.1080 / 01674820902830276$

[50] Sadock B, Sadock V. Synopsis of psychiatry, 9th ed. USA: Lippincott Williams and Wilkins. 2004.

[51] Rashidi B, Montazeri A, Ramezanzadah F, et al. Health related quality of life in infertile couples receiving IVF or ICSI treatment. BMC health services research, 2008; 8: 186-187. PMid:18803838 http://dx.doi.org/10.1186/1472-6963-8-186

[52] Beutel M, Kupfer J, Kirchmeyer P, et al. Treatment related stress and depression in couples undergoing assisted reproductive treatment by IVF or ICSI. Andrologia. 1999; 31(1): 27-35. http: //dx.doi.org/10.1111/j.1439-0272.1999.tb02839.x

[53] Noorbala A, Mohammad A, Bagheri S. Prevalence of psychiatric disorder in Tehran (Iran) Hakim J. 1999; 2: 214-223.

[54] Ramezanzadeh F, Aghssa M, Abedinia N, et al. A Survey of Relationship between Anxiety, Depression and Duration of Infertility. BMC women's health. 2004; 4: 9. PMid:15530170 http: //dx.doi.org/10.1186/1472-6874-4-9

[55] Boivin J. A review of psychological interventions in infertility. Soc Sci Med. 2003; 57: 2325-2341. http://dx.doi.org/10.1016/S 0277-9536 (03) 00138-2

[56] Waddell A. Women's health, improve our health, improve the world, Geneva: Who, 1995; 6-8.

[57] Sharma V, Khandpur S. Epidemiology of sexually transmitted infections. Sexually transmitted diseases and HIV/AIDS. 2nd edition, Issue 1, Viva Books, New Delhi; 2009: 16-17.

[58] Thekdi K, Mehta P, Thekdi P, et al. Fertility Profile, Anxiety, Depression of Married Women and Its Association with Reproductive Tract Infections in the Rural Area of Surendranagar District. Scholars Journal of Applied Medical Sciences (SJAMS). 2014; 2(1A): 104-108.

[59] Patel V, Betty R. Gender disadvantage and Reproductive Health Risk factors for common mental disorders in women, a community survey in India. Arch Gen Psychiatry. 2006; 63(4): 404-413. PMid:16585469 http://dx.doi.org/10.1001/archpsyc.63.4.404

[60] Cai WD, Wu S, Luo L. Reproductive tract infections-a main factor influencing women's mental status: Comparison on depression and anxiety between Naxi women with and without RTIs. Journal of Reproduction and Contraception. 2007; 18(2): 145-154. http://dx.doi.org/10.1016/S1001-7844(07)60018-2

[61] Kee B, Jung B, Lee S. A study on psychological strain in IVF patients. J Assist Report Genet. 2000; 17: 445-448. PMid:11062855 http://dx.doi.org/10.1023/A: 1009417302758

[62] Berg B, Wilson J. Psychological functioning across stages of treatment of infertility. J Beh Med. 1991; 1: 11-26. http://dx.doi.o $\mathrm{rg} / 10.1007 / \mathrm{BF} 00844765$

[63] Dhaliwal L, Gupta K, Gopalan S, et al. Psychological aspects of infertility due to various causes-Prospective study. Int J Fertil Womens Med. 2004; 49: 44-8. PMid:15038509

[64] Domar A, Moragianni V, Ryley D, et al. The risks of selective serotonin reuptake inhibitor use in infertile women: A review of the impact on fertility, pregnancy, neonatal health and beyond. Human Reproduction. 2013. http://dx.doi.org/10.1093/humrep/de s383 